\title{
Identification of Students' Interest of Literacy at College As A Form of Cultural Conservation
}

\author{
Haryadi, Riza Arifudin, Asep Purwo Yudi Utomo, Uki Hares Yulianti \\ Graduate School, Universitas Negeri Semarang, Indonesia \\ Haryadihar67@mail.unnes.ac.id
}

\begin{abstract}
Many problems regarding literacy need to be explored and examined in depth. An alarming fact is recognized from the ranking of international literacy, which reveals the fact that the ability to read and write Indonesian people is very left behind. Indonesia is ranked 60th out of a total of 61 countries. This is not without any reason, the culture of reading (bookkeeping) and literacy of Indonesian people lags behind four years compared to other countries. This research is a field study research that intends to study intensively about literacy in universities. Descriptive research is a research that prioritizes the description of events that occur and take place in present or in the past. The approach used in this study is a qualitative approach, which intends to understand the phenomenon of what is experienced by research subjects, such as behaviour, perception, views, motivation, and daily actions. The results of this study found the percentage of findings related to students' reading interest in college. Of all the components of the question, it was quantitatively concluded that students' reading interest in college was still low. This was measured by several indicators, including reading needs, reading difficulties, reading goals and techniques, references and lectures.
\end{abstract}

Key words: literacy, reading interest, college

\section{Introduction}

Literacy culture is currently being heavily campaigned, especially in the world of education. This is not without reason, as reported in online media tempo.co (2017) reports that according to Muhajir Effendy (Minister of Education and Culture), the reading culture (bookkeeping) and literacy of Indonesian society lags behind four years compared to other countries. It is described by Minister Muhadjir with grade 3 (grade XII) high school students' literacy or reading ability in Indonesia is the same as the literacy of second grade students (grade VIII) in a number of countries. In fact, in certain regional schools, students still cannot read smoothly. Regarding this issue, the bookkeeping or literacy problem is very urgent and must be straightened out and the hope is that the Bill on the Bookkeeping System will be ratified immediately.

The news provides an overview of the issues of literacy that are of concern to the government. The number of educational problems certainly has the roots of the problem that must be resolved, one of which is the problem of literacy.

The same thing was conveyed at mediaindonesia.com on August 30, 2016, it explained that based on the results of Central Connecticut State University research in New Britain in collaboration with a number of social researchers put Indonesia in $60^{\text {th }}$ rank out of 61 countries related to reading interest. The survey was conducted from 2003 to 2014. Indonesia was only superior compared to Bostwana who was satisfied in 61st position.

Republika.co.id, an online media, also explained the same thing, that the results of the Program for International Student Assessment (PISA) study stated that the literacy culture of the Indonesian people in 2012 was the second worst of 65 countries studied in the world. Indonesia ranks 64 th out of 65 countries. While Vietnam ranks in the top 20. In the same study, PISA also placed the reading position of Indonesian students in 57th out of 65 countries studied. PISA said that there was no single student in Indonesia who achieved literacy grades at the fifth level, only 0.4 percent of students had fourth level literacy skills. The rest of those are below level three, even below level one. UNESCO 2012 statistical data states that the reading interest index in Indonesia has only reached 0.001 .

These global problems are also found in the world of education, especially on campus. Students who should have a high literacy level have not been able to meet these expectations. Many weaknesses arise and need attention of researchers to find out and overcome these problems. On the basis of these problems, the purpose of this study was to identify students' 
reading interest in higher education as a form of cultural literacy and conservation.

The previous research that was studied in this study was taken from various results of research that had been done about the narration, among others: in 2016 examined the Development of the Literacy Study Centre Model to Increase Reading Comprehension of Students of Semarang State University. There are findings related to how weak the student's reading ability is, but the exact cause of the problem is not yet known. In the Journal of Educational Sciences, Volume 20, Yuliati (2014) examined related literacy culture with the title "Read-Write Model Based on Balance Literacy and Literacy Movement in Elementary School". The research describes literacy problems that have arisen since elementary school.

In the value of language learning, literacy is defined as literacy, competence or skills in reading and writing. Literacy, in English, comes from the Latin littera (letters) which involves mastering the writing systems and conventions that accompany them. However, literacy primarily relates to language and how it is used. The written language system is secondary. Talking about language, of course, cannot be separated from talking about culture because language itself is part of culture. Thus, defining the term literacy must certainly include the elements that encompass the language itself, namely the socio-cultural situation.

Tompkins (1991: 18) states that Literacy is closely related to the term smoothly-reading ability. Literacy is broadly interpreted as language skills that include the ability to listen, speak, read, and write, and the ability to think that is an element in it. In a broad sense, literacy includes language skills (listening, speaking, reading, and writing) and thinking that is an element in it. Based on this opinion literacy is closely related to reading and writing skills. In this study, it will focus on more studies on aspects of writing.

\section{Methods}

This research is a field study one that intends to study intensively about literacy in universities. Descriptive research (descriptive research) is research that prioritizes the description of events that occur and that take place in the present or in the past.

This research does not carry out manipulation or alteration on independent variables, but describes about literacy in universities the way it is. Especially related to reading and writing habits and students' reading and writing skills in college. This study aims to identify and characterize literacy culture in universities.

The approach used in this study is a qualitative approach, which intends to understand the phenomenon of what is experienced by research subjects, such as behaviour, perception, views, motivation, daily actions, holistically and with methods of description in the form of words and languages (narrative) in a special natural context and by utilizing various natural methods. This approach is used because the data obtained is descriptive data in the form of written and spoken words from people and in the form of documents or observed behaviour.

\section{Results and Discussion}

Identification of students' reading interest in higher education as a form of literacy and cultural conservation includes the indicators of: (1) reading needs, (2) reading difficulties, (3) reading techniques, (4) reading goals, and (5) references in lectures. The indicators discussed are those that are most related to identifying students' interest in reading without ignoring the other ones.

\section{Reading Needs}

Identification and characterization of students' reading interest in higher education as a form of literacy and cultural conservation with the indicators of student needs include the following.

Table 1. The Pleasure of Reading

\begin{tabular}{cll}
\hline Indicator & Answer choice & Percentage \\
\hline The & enthusiastic to read & $9.5 \%$ \\
Pleasure & interested to read & $69.9 \%$ \\
of & less willing to read & $20.2 \%$ \\
Reading & not like reading & $0.4 \%$ \\
\cline { 2 - 3 } & Total & $100 \%$ \\
\hline
\end{tabular}

Based on table 1, of the 1218 respondents, it was concluded that the students who were enthusiastic to read were $9.5 \%$, interested to read were $69.9 \%$, less willing to read were $20.2 \%$, and the rest of those did not like reading. On the basis of these data, it was confirmed that the pleasure of reading they did was the pleasure of reading on social media. 
This illustrates that students are still ignoring the appropriate book or reading activity. However, this is different from another data regarding reading routines.

Table 2. Reading Routines

\begin{tabular}{cll}
\hline Indicator & Answer choice & Percentage \\
\hline Reading & keep regularly & $9.9 \%$ \\
Routines & reading & \\
& often read & $29.6 \%$ \\
& sometimes read & $60.3 \%$ \\
& never read & $0.2 \%$ \\
\cline { 2 - 3 } & Total & $100 \%$ \\
\hline
\end{tabular}

Based on table 2, out of 1218 respondents, it was concluded that those who keep regularly reading were $9.9 \%$, often read were $29.6 \%$, sometimes read were $60.3 \%$, and the rest of those never read. This result is a proof that students' reading ability is very influential with reading routines. Students do not routinely read because they are influenced by their reading ability. Reading routines are also influenced by behaviour, one of which is how they schedule reading activities.

A data on reading schedules made by students stated that students who often schedule to read are only $11 \%$, sometimes schedule to read are $51.4 \%$, and never schedule to read are $35.3 \%$. Only a small number of them who really plan to read every day. However, there are other data about the time they used to read, the results are quite good. However, the intended time considered as reading time is when they go to college. The discussed data shows that students who read more than 4 hours are only up to $3.4 \%$, read 3-4 hours are 9.6\%, read 1-2 hours are $49.6 \%$, and read less than 1 hour are $37.4 \%$.

The things that have been discussed can be confirmed by student habits contained in the following data.

Table 3. Students' Literacy

\begin{tabular}{cll}
\hline Indicator & Answer choice & Percentage \\
\hline $\begin{array}{c}\text { Students' } \\
\text { Literacy }\end{array}$ & $\begin{array}{l}\text { often read news or } \\
\text { stories on social } \\
\text { media more } \\
\text { often read college } \\
\text { books } \\
\text { often read blogs and } \\
\text { online portals } \\
\text { read the other } \\
\text { sources }\end{array}$ & $86.7 \%$ \\
\cline { 2 - 2 } & $16.9 \%$ \\
\hline
\end{tabular}

Based on table 3, out of 1218 respondents, it was concluded that $46.6 \%$ often read news or stories on social media more, $27.8 \%$ often read college books, $8.7 \%$ often read blogs and online portals, and the rest of those read the other sources. On the basis of this data, it is shown that student literacy that students read more on social media than college books that they are actually supposed to read. Awareness of developing reading material is still lacking and limited.

\section{Reading Difficulties}

Identification and characterization of students' reading interest in higher education as a form of literacy and cultural conservation indicators of reading readiness include the following.

Table 4. Reading difficulties

\begin{tabular}{cll}
\hline Indicator & Answer choice & Percentage \\
\hline $\begin{array}{c}\text { Reading } \\
\text { difficulties }\end{array}$ & $\begin{array}{l}\text { always had reading } \\
\text { difficulties } \\
\text { often had reading } \\
\text { difficulties } \\
\text { sometimes had } \\
\text { reading difficulties } \\
\text { never have difficulty } \\
\text { in reading }\end{array}$ & $\begin{array}{l}16.4 \% \\
\text { Total }\end{array}$ \\
\hline
\end{tabular}

Based on table 4, out of 1218 respondents, it was concluded that $1.3 \%$ of students always had reading difficulties, $16.4 \%$ of students often had reading difficulties, $72.4 \%$ of students sometimes had reading difficulties, and $9.9 \%$ of students never have difficulty in reading. On the basis of these data and based on confirmation, almost no students did not have reading difficulties.

Table 5. The Causing of Reading Difficulties

\begin{tabular}{|c|c|c|}
\hline Indicator & Answer choice & Percentage \\
\hline \multirow{6}{*}{$\begin{array}{l}\text { The } \\
\text { Causing of } \\
\text { Reading } \\
\text { Difficulties }\end{array}$} & environmental & $49 \%$ \\
\hline & disturbances & \\
\hline & the text to read & $22.2 \%$ \\
\hline & self-ability & $24.6 \%$ \\
\hline & $\begin{array}{l}\text { the rest are } \\
\text { recognized }\end{array}$ & $4.2 \%$ \\
\hline & Total & $100 \%$ \\
\hline envirol & $\begin{array}{l}\text { on table } 5 \\
\text { it was } \\
\text { disturbances }\end{array}$ & $\begin{array}{rr}\text { of } 1218 \\
\text { uded } & \text { that } \\
49 \% & \text { role }\end{array}$ \\
\hline
\end{tabular}


causing reading difficulties, the text to read had a role of $22.2 \%$ causing reading difficulties, selfability had a role of $24.6 \%$ causing reading difficulties, the rest are recognized as the other causes. Environment becomes the most dominant thing as an obstacle or cause of reading difficulties. However, the interesting thing is that self-ability is one of the dominant reasons for reading difficulties.

Even though they have difficulty in reading, only a small number of them will really want to find out the solution and some don't ask the right person or find out the right book. This was reflected in the data that only $10.6 \%$ of those who always tried to overcome reading difficulties, $31.1 \%$ who often, $51.1 \%$ who sometimes, and $7.1 \%$ who never tried to. In addition, $64.1 \%$ of students asked their classmates when they had difficulty in reading, $16.5 \%$ of students asked their boarding friends, and the rest were for the other circumstances. Other related data states that $56.6 \%$ of them have never read a book that can overcome reading difficulties, $36.4 \%$ sometimes, and the rest find the other solutions.

\section{Reading Objectives and Techniques}

Identification and characterization of students' reading interest in higher education as a form of literacy and cultural conservation of objective indicators and reading techniques include the following.

Table 6. Reading Techniques

\begin{tabular}{cll}
\hline Indicator & Answer choice & Percentage \\
\hline Reading & $\begin{array}{l}\text { never used the same } \\
\text { Techniques }\end{array}$ & $22.6 \%$ \\
& $\begin{array}{l}\text { reading method reading } \\
\text { sometimes the same } \\
\text { reading method } \\
\text { when reading } \\
\text { often the same } \\
\text { reading method } \\
\text { when reading } \\
\text { not know any }\end{array}$ & \\
\cline { 2 - 3 } & Total & $5.6 \%$ \\
\hline
\end{tabular}

Based on table 6, out of 1218 respondents, it was concluded that $22.6 \%$ never used the same reading method when reading, $55.6 \%$ sometimes, $16.6 \%$ often, and the rest of those did not know any. This means that not all students know good reading techniques. This results in a lack of priority in reading in accordance with the data that $10.4 \%$ of students never decide which part to read, $40.4 \%$ sometimes, $48.6 \%$ often, and the rest do not know. It also relates to how students determine the purpose of reading.

Table 7. Reading Goal

\begin{tabular}{cll}
\hline Indicator & Answer choice & Percentage \\
\hline Reading & never determined & $7.1 \%$ \\
Goal & reading goals & \\
& sometimes & $39.7 \%$ \\
& often & $51.9 \%$ \\
& never & $1.3 \%$ \\
\cline { 2 - 3 } & Total & $100 \%$ \\
\hline
\end{tabular}

Based on table 7, of 1218 respondents, it was concluded that $7.1 \%$ never determined reading goals, $39.7 \%$ sometimes, $51.9 \%$ often, and the rest never. Even though it is more than $50 \%$ does not mean this is a good record because determining goals should be a must in reading. Determining goals must be supported by the different speed ability to read like a data that shows $8.8 \%$ of students who always see the main parts of reading / overall reading, $41.2 \%$ often, 43.4 sometimes, and the rest never. Other data states that $44.5 \%$ of students often read at an unequal pace, $46.6 \%$ sometimes, and the rest are always and never.

These data are in line with Awai (2016) which suggests that reading or literacy requires treatment, nothing can change instantly because everything takes time.

\section{References in Lectures}

The quality and quantity of student reading literacy is also influenced by the assignments given by the lecturer. The task for this question is the direction to choose the references used in the lecture. Initial data is very influential, namely the number of lecturers who suggest referring references.

Table 8. Students' Interest

\begin{tabular}{cll}
\hline Indicator & Answer choice & Percentage \\
\hline Students' & often asked to read & $46.7 \%$ \\
Interest & reference books & \\
& sometimes & $26.7 \%$ \\
& always & $25.6 \%$ \\
& never & $1 \%$ \\
\cline { 2 - 3 } & Total & $100 \%$ \\
\hline
\end{tabular}

Based on table 8, out of 1218 respondents, it was concluded that $46.7 \%$ of students stated that lecturers often asked to read 
reference books, $26.7 \%$ sometimes, $25.6 \%$ always, and the rest never. This is related to students' interest in reading because it affects the type of reading chosen by students.

Of the many lecturers asking students to read, the $47.9 \%$ of students sometimes are asked to read reference book by the lecturers, $36.7 \%$ are often, $11.4 \%$ always, and the rest are never. This data is supported by the other data stating that $55.7 \%$ of lecturers sometimes determine the minimum reference book that must be read, $21.8 \%$ never, $17.4 \%$ often, and the rest always. That is, lecturers have a role to improve reading literacy of students. Furthermore, the latest data suggests that $50 \%$ the lecturer sometimes gives a task as a follow-up, you read the references, $36.5 \%$ often, $7.8 \%$ always, and the rest never.

Another interesting thing about the reference task as one of the literacy boosters is the follow-up of the activity.

Table 9. Reading Assignments

\begin{tabular}{cll}
\hline Indicator & Answer choice & Percentage \\
\hline Reading & sometimes have & $57.4 \%$ \\
Assignments & discussed your & \\
& reading & \\
& assignments & \\
& often & $24.8 \%$ \\
& never & $13.2 \%$ \\
& always & $4,6 \%$ \\
\cline { 2 - 3 } & Total & $100 \%$ \\
\hline
\end{tabular}

Based on table 9, out of 1218 respondents, it can be concluded that $57.4 \%$ lecturers sometimes have discussed your reading assignments, $24.8 \%$ often, $13.2 \%$ never, and the rest always. On the basis of these data illustrates that only $24.8 \%$ of lecturers often confirm student reading assignments.

\section{Conclusion}

On the basis of the results of the research presented, the following matters were concluded. In this study found the percentage of findings related to students' interest in reading in college. Of all the components of the question, it was quantitatively concluded that students' reading interest in college was still low. This was measured by several indicators, including reading needs, reading difficulties, reading goals and techniques, references and lectures. These indicators are interrelated between one another and complement each other's student reading weaknesses and findings that can be developed to improve students' abilities. On the basis of data, it is a measure of reading literacy for students whose reading interests are more on social media than on college books that they should actually read. Awareness of developing reading material is still lacking and limited. Even though they have difficulty in reading, only a small number of those who really want to find out the solution and some don't ask the right person or find out the right book. The quality and quantity of student reading literacy is also influenced by the assignments given by the lecturer. The task in this problem is the direction to choose the references used in the lecture.

\section{References}

Cook, Summer B.; Marvin Druger; Lori L. Ploutz-Snyder. (2011). Scientific literacy and attitudes towards American space exploration among college undergraduates. Elsevier. Space Policy.

Drouin, M.A. (2011). College students' text messaging, use of textese and literacy skills. Wiley Blackwell (Blackwell Publishing). Journal of Computer Assisted Learning.

Gross, Melissa; Don Latham. (2012). What's skill got to do with it?: Information literacy skills and self-views of ability among first-year college students. Wiley Blackwell (John Wiley \& Sons). Journal of the American Society for Information Science and Technology.

https://nasional.tempo.co/read/news/2017/03/22/ 173858608/menteri-pendidikan-literasiindonesia-tertinggal-4-tahun. Accessed on Thursday, June 8, 2017.

http://www.republika.co.id/berita/koran/didaktik a/14/12/15/ngm3g840-literasi-indonesiasangat-rendah. Accessed on Thursday, June 8, 2017.

http://mediaindonesia.com/news/read/64231/min at-baca-indonesia-peringkat-60-dari-61negara/2016-08-30. Accessed on Thursday, June 8, 2017.

Iwai, Yuko. (2016). The Effect of Explicit Instruction on Strategic Reading in a Literacy Methods Course. International Journal of Teaching and Learning in Higher Education. 2016, Volume 28, Number 1, 110-118

Kreitzer, Mary Jo; Victor Sierpina; Susan Fleishman. (2010). Teaching Research Literacy: A Model Faculty Development Program at Oregon College of Oriental 
Medicine. Elsevier. EXPLORE: The Journal of Science and Healing.

Mei-yun Ko, Tzu-Fu Wang. (2013). EFL Learners' Critical Literacy Practices: A Case Study of Four College Students in Taiwan. Springer-Verlag. The AsiaPacific Education Researcher.

Miller, Richard E. (2012). Thomas P. Miller. The Evolution of College English: Literacy Studies from the Puritans to the Postmoderns. Pittsburgh, PA: University of Pittsburgh Press, 2011.
344 pp. Paper \$27.95. Wiley Blackwell (Blackwell Publishing). History of Education Quarterly.

Tompkins, Gail E. dan Kenneth Hoskisson. (1991). Language Arts: Content and Teaching Strategies. New York: Max Well Macmillan International Publishing Group.

Yuliati. (2014). "Model Baca-Tulis Berbasis Balance Literacy dan Gerakan Literasi di SD”. Jurnal Ilmu Pendidikan. 20(1): 117-126. 